\title{
Betonarme Binalar için Perde Duvar Etkinliğinin Belirlenmesi
}

\author{
Barış ERDİL, Yusuf GÜNDÜZ \\ Van Yüzüncü Yll Üniversitesi, Mühendislik Fakültesi, Inşaat Mühendisliği Bölümü, 65080, Van, Türkiye \\ (ORCID: 0000-0001-5282-3568) (ORCID: 0000-0001-6054-4753)
}

\begin{abstract}
Öz
Betonarme binaların güçlendirilmesi durumunda kullanılacak perde duvarların kat alanına oranı ile ilgili olarak çeşitli öneriler geliştirilmiştir. Önerilen oranlar global anlamda olup bu oranların perde duvarlar sayısı ve/veya konumu ile ilişkisi üzerinde durulmamıştır. Örneğin \%1 oranında perde duvar kullanılması ile kontrollü hasar performans seviyesinin sağlanacağı belirtildiğinde, bu \%1'lik perde duvarın en fazla kaç parçaya bölünebileceği, bölünen bu perde duvarların planın hangi noktasında daha etkin olabileceği hususu belirsizdir. Bu belirsizlikler sebebi ile mühendisler çoğunlukla deneme yanılma yöntemi ile perde duvarları yerleştirmektedir. Bu çalışmada betonarme binaların güçlendirilmesi durumunda kullanılacak perde duvarların etkinliğini belirlemek amacı ile farklı sayı ve kalınlıkta tasarlanmış perde duvarlar, planda farkı alanlara yerleştirilmiştir. Yapılan analizler neticesinde aynı alana sahip perde duvarların parçalara ayrılarak binaya yerleştirilmesinin perde duvar kesme kuvveti ve moment etkinliğini azalttığı, perde duvar boyunun kısalması neticesinde binanın global rijitliğinin azaldığı ve nihayetinde deplasmanlar ile periyotların arttı̆̆ arttıkça azalmaktadır. Perde duvarların bina merkezine yakın yerleştirilmeleri ile kesme kuvveti etkinlikleri artırılmakta, göreli kat ötelemeleri ve yapı periyodu düşmektedir. Dış akslara perde duvar yerleştirilmesi ile de perde duvarların moment etkinlikleri artırılabilmektedir.
\end{abstract}

Anahtar kelimeler: Betonarme, Perde Duvar, Deprem Performansı

\section{Determination of the Shear Wall Efficiency in Reinforced Concrete Buildings}

\begin{abstract}
Various recommendations have been proposed regarding the ratio of shear walls to floor area to be used in case of strengthening of reinforced concrete buildings. Since the researchers proposed global ratios, the relationship of these proportions to the number and/or location of shear walls were not considered. For example, when it is stated that a life safety performance level will be achieved by using a $1 \%$ shear wall, it is unclear that how many pieces this $1 \%$ shear wall can be divided into and at what location in the plan these divided shear walls can be more effective. Because of these uncertainties, engineers often place shear walls by trial and error. In this study, shear walls designed in different numbers and thicknesses were placed in different areas in the plan in order to determine the effectiveness of shear walls to be used in case of strengthening of reinforced concrete buildings. As a result of the analysis, it was determined that keeping the shear wall area the same but dividing and placing them in appropriate locations in the plan decreases the shear force and moment effectiveness of the shear walls. Besides, since the length of the shear wall reduces when it is divided, the global stiffness of the building decreases and ultimately the displacements and periods increase. Shear wall efficiency decreases with increasing number of stories. Placing shear walls near the center of the building increases their shear force carrying efficiency but reduces the roof displacements and fundamental periods. However, when the shear walls are placed at the exterior grids, it is possible to increase their moment carrying efficiency.
\end{abstract}

Keywords: Reinforced Concrete, Shear Wall, Seismic Performance.

\section{Giriş}

Aktif deprem kuşağında olan ülkemizde 1900 yılından günümüze değin yaşanmış olan büyük depremlerde 66702 vatandaşımız hayatını kaybederken 348241 adet konut da bu depremlerde ağır hasar

*Sorumlu yazar: bariserdil@yyu.edu.tr

Geliş Tarihi: 17.03.2021, Kabul Tarihi: 17.05.2021 
almıştır. 2011'de yaşanan Van depremlerinde 36203'ü konut olmak üzere 48689 binanın ağır hasar gördüğü veya göçtüğü, 18181'i konut olan 22483 binada orta hasar meydana geldiği ve 93238'i konut olmak üzere 115204 binanın ise hafif hasar gördüğü veya hasarsız olduğu ifade edilmektedir [1]. Hasar tespit incelemesinin genel sonuçlarına bakıldığında konutların \%76'sının, iş yerlerinin \%79'unun ve ahırların \%82'sinin hasarlı olduğu görülmektedir (Şekil 1).

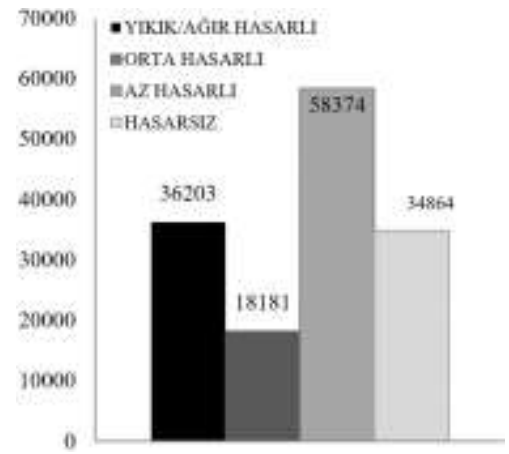

a) Konut

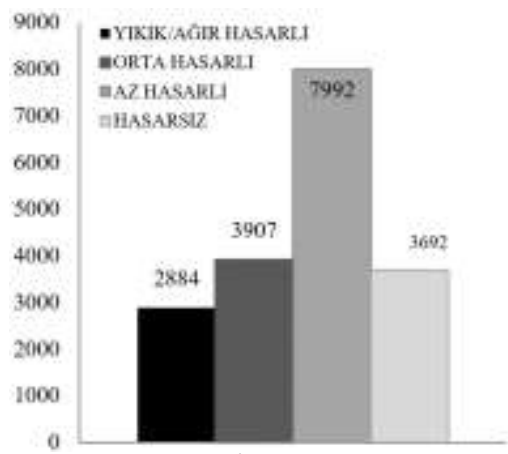

b) İşyeri

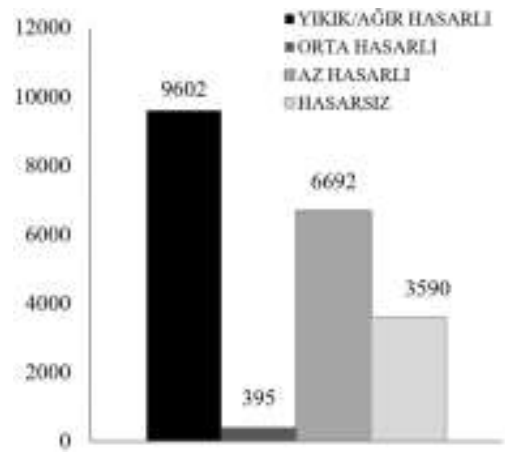

c) Ahir

Şekil 1. 2011 Van depremleri sonrası binalar üzerinde yapılan inceleme sonuçları

Türkiye'de depreme dayanıklı yapı ilkeleri, bina kalitesini arttırmak amacı ile her büyük deprem sonrası yeni yönetmelikler ile güncellenmekte ve gelişim göstermektedir. Teknolojinin hızlı gelişimi neticesinde daha detaylı ve gerçekçi yapısal analizler yapılabilmektedir. Bu durum teknoloji ile birlikte projelendirmedeki kalite artışını da beraberinde getirmiştir. Fakat 2011 Van depremleri uygulamadaki kalite artışının yavaş olduğunu göstermiştir. Kalite artışındaki bu yavaşlık, yaşanan her depremde ciddi miktarda binanın hasar görmesine ve can kaybına sebep olmuştur [2]. Kalitenin yanında taşıyıcı sistem elemanların yerleşimi ve boyutunun da yapı performansında etkili olduğu son depremlerdeki gözlemlerde öne çıkmıştır [3,4]. Perde duvar hasarlarının incelenmesi neticesinde perde uç bölgesi, eksenel yük miktarı, kesme donatısının yerleşimi, perde duvarın uzunluk/kalınlık oranı vs. faktörlerinin önemli olduğu vurgulanmış, perde duvarlardaki detay eksikliklerinin perde duvar etkinliğini olumsuz etkileyebileceği ifade edilmiştir [5].

Ülkemizin ve diğer ülkelerin hazırlamış oldukları deprem yönetmelikleri yapının bir miktar elastik ötesi davranış sergileyeceği varsayımına göre düzenlenmiştir. Yatay bir yük olan deprem karşısında yatay rijitliği küçük olan yapılar deprem etkisi altında büyük ötelemeler yapmaktadır. Yatay ötelemelerin büyük olması kolon uçlarında ikinci mertebe momentlerinin artmasına yol açmakta, mevcut halde var olan momentlere ikinci mertebe momentlerinin de eklenmesiyle belli bir moment kapasitesi olan kolonlarda moment kapasitesinin aşlarak hasarların kaçınılmaz olmasına sebep olmaktadır. Deprem sonucu yapıya etkiyen yatay yüklerin oluşturduğu yatay ötelemeleri sınırlandırmak için yapının yatay rijitliğini arttırmak gereklidir. Bunu sağlayabilmek için düşey taşıyıcı elemanların belirli boyutlarda tasarlanması gerekmektedir. Perde duvar kullanılmadığı durumda kolon boyutları binanın her iki doğrultusunda da büyüyeceğinden perde duvar kullanılarak kolon boyutları küçültülmekte ve böylelikle binadaki kullanım alanı artırılmaktadır. Tamamıla perdelerden oluşturulmuş bir sistemde eğilme momenti altında katlar arası en büyük yer değiştirme üst katlarda meydana gelirken, çerçeve sistemde alt katlarda oluşmaktadır [6]. Bu iki davranışı sergileyen perde ve çerçeve sistemler birlikte kullanıldığında hem eğilme hem de kayma davranışı etkili olmaktadır. Oluşan karma sistemde yapının üst kısmındaki perde duvar eğilmesi çerçeve tarafindan, çerçevenin alt katlarındaki kaymalar ise perde duvarlar tarafından sınırlandırılmış olur [7].

Perde duvarların miktarı yapının yatay yük taşıma kapasitesi ile göreli kat ötelemelerini doğrudan etkilemektedir [8-10]. Dinamik analizler neticesinde düşük perde duvar miktarına sahip binalarda büyük deplasman talepleri ortaya çıkabilmekte ve yüklerin çerçeve elemanlar ile perde duvarlar arasındaki dağılımının değişmesine ve moment eğrisinin eğiminin artmasına sebep olabilmektedir. Bu sebeple can güvenliği performans seviyesinin karşlanabilmesi için perde duvar oranının binanın her bir doğrultusu için \% 0.6 olması önerilmektedir. Ayrıca bina periyodunun tasarım spektrumunda ivme-sabit bölge ile çakışması durumunda perde duvar oranının \%1.5'e çıkarılması tavsiye edilmektedir [7]. Bir başka çalışmada ise perde duvar oranının $\% 1$ olduğu düşük ve orta 
yükseklikteki binalarda göreli kat öteleme oranının \%2'nin altında olduğu, bu binalarda can güvenliği performans seviyesinin karşılanabileceği belirtilmektedir [11]. Bazı çalışmalarda ise depremin her doğrultusu için perde duvar miktarı $\left(\sum A_{w i}\right)$ toplam kat alanına $\left(\sum A_{f}\right)$ veya binanın taban alanına $\left(A_{f t}\right)$ göre Eş.1, Eş.2ve Eş.3’teki gibi verilmektedir.

$$
\begin{aligned}
& \sum A_{w i}=\frac{\sum A_{f}}{750} \\
& \sum A_{w i} \geq 0.0012 \sum A_{f} \\
& \sum A_{w i} \geq 0.004 A_{f t}
\end{aligned}
$$

Perde duvarlar sahip oldukları rijitliklerinden ötürü yapının rijitlik merkezini de önemli ölçüde etkilemektedir. Deprem yönetmeliklerinde yapıda deprem esnasında burulma olmaması için kütle ve rijitlik merkezlerinin olabildiğince birbirlerine yakın olmaları gerektiği belirtilmektedir. Yapıda en büyük burulma rijitliğinin sağlanması için kullanılan perde duvarların olabildiğince yapının dış kısımlarına yerleştirilmesi gerektiği, dış kısımlara yerleştirilen perde duvarlara sahip yapının yer değiştirmesinin çok az etkilendiği ancak bunun önemsenmeyecek düzeyde olduğu belirtilmiştir [14,15].

Basit bir çerçeve içerisine tam veya yarım yerleştirilmiş perde duvarların yapının yatay yük taşıma kapasitesini önemli düzeyde artırdığı, perde duvar eklenmesi ile yapıların güçlendirilebileceği deneysel çalışmalar neticesinde açıklığa kavuşturulmuştur [16]. Betonarme çerçevelere diştan perde duvar ilavesi ile yük taşıma kapasitesinin yaklaşı 3 kat, rijitliğin ise yaklaşık 4 kat artabileceği 2 katlı 3 açıklı çerçeve deneyleri üzerinden belirlenmiştir [17]. Ayrıca perde duvarlı binaların genel olarak iyi tasarlandığı ve deprem performanslarının da iyi olduğu 2010 Şili depremlerinde gözlenmiştir. Bu gözlemlerde perde duvarların dayanım fazlalığının etkili olabileceği düşünülmüş ve az-orta-çok katlı betonarme perde duvarlı binalar analiz edilmiştir. Analizler neticesinde 5 katlı bir binada dayanım fazlalığının 4'ten büyük olduğu, 17 katlı bir binada bu değerin yaklaşık 2 olduğu, 26 katlı binada ise yaklaşık 1.5 olduğu tespit edilmiştir [18]. Bir başka çalışmada dayanım fazlalığı katsayısının binanın rijitliğine bağlı olduğu, rijitlik azaldıkça dayanım fazlalığı katsayılarının düştüğü belirlenmiştir. Rijitlik düştükçe binanın yatay deplasman talebi artmakta ve bu durum perde duvarların daha fazla zorlanmasına sebep olmaktadır [19]. Dayanım fazlalığı katsayısı iç kuvvet talebi ile kapasitenin ilişkisini ifade ettiğinden kapasiteyi etkileyen faktörlerin önemli olduğu, perde uç bölgelerindeki donatıların moment kapasitesi için, gövde donatılarının da kesme kuvveti dayanımı için gerekli olduğuTBDY2018 [20] ve diğer çalı̧̧malarda belirtilmiştir $[7,21]$.

Ülkemizde betonarme binaların güçlendirilmesinde perde duvarlar yaygın olarak kullanılmakla beraber kullanılacak perde duvarların miktarı ve plandaki yerleri hakkında pratik bir yaklaşım henüz öne sürülmemiştir. Bu sebeple yapılar güçlendirilirken tamamen analiz programları üzerinden deneme yanılma yöntemi ile tasarım yapılmakta, buna bağlı olarak da ek maddi külfet oluşmaktadır. Ayrıca programlar aracılığı ile yapılan analizler sırasında perde duvarın yerleştirildiği yerin yapı davranışına ve perde duvara etkisi tam olarak bilinmediğinden dolayı perde duvarların yerleşimi keyfi yapılmakta, bu da tasarım sirasında zaman almaktadır.

Literatürde binalarda can güvenliği performansının sağlanabilmesi için gerekli minimum perde duvar miktarı verilmesine rağmen bu perde duvarların hangi büyüklüklerde kullanılması gerektiği ve kat planının neresinde daha etkili olacağı ile ilgili bilgiler eksik bırakılmıştır. Bu çalışmada 2 farklı taban alanına, 2-8 arası kat adedine ve 3 farklı perde kalınlığına ve 3 farklı perde duvar sayısına göre oluşturulmuş toplam 315 model analiz edilerek perde duvarların etkinliği araştırılmıştır.

\section{Materyal ve Metot}

Çalışma kapsamında perde duvar konumu ve miktarının kesme kuvveti, moment, yapı periyodu ve deplasmanlar üzerine etkisi iki yönlü simetriye sahip binalar üzerinden araştırılmıştır. İlk yapı (M1) 144 $\mathrm{m}^{2}$ taban alanına sahip olup küçük binaları temsil etmekte, diğer yapı (M2) ise $480 \mathrm{~m}^{2}$ taban alanına sahip büyük yapıları temsil etmektedir. İki yapıda da referans olarak ele alınan ilk modelde (M1-1 ve M2-1) binanın orta aksına bir adet perde duvar yerleştirilip analiz edilmiştir. Daha sonra merkezdeki 
perde duvar önce iki eşit parçaya bölünmüş ve simetrik olacak şekilde diğer akslara dağıtılmıştır. Son olarak merkezdeki perde duvar dört eşit parçaya bölünmüş ve burulma oluşturmayacak şekilde simetrik olmak kaydıyla binanın diğer akslarına yerleştirilerek analizler yapılmışır. Modeller, sonuçları kolay takip edebilmek için kodlanmıştır. Örneğin M2-2-r025 şeklinde kodlanan modelde M2 $480 \mathrm{~m}^{2}$ lik yapıyı, bundan sonra gelen sayı bu yapı grubundaki 2. modeli ve ardından gelen bölüm ise (r025) perde duvar oranını belirtmektedir.

\section{1. Çalışmada kullanılan binaların özellikleri ve modelleme}

Çalışmada 2 farklı kat alanına, 3 farklı perde duvar kalınlığına (kalınlık $\mathrm{t}_{\mathrm{w}} 20,30,40 \mathrm{~mm}$ arasında değişmektedir), 2-8 arası kat sayısına ve 3 farklı perde duvar sayısına (tek perde duvar, 2 perde duvar ve 4 perde duvar) sahip toplam 315 model SAP2000v20 sürümü ile analiz edilmiştir [22] (Tablo 1, Şekil 2 ve Şekil 3). Tüm yapıların kat yüksekliği 3 m olarak sabit tutulmuş, perde duvar dışında kalan akslara 40x40 cm ebatlarında kolonlar yerleştirilmiştir. Tüm kirişler 30x60 cm ve tüm döşeme kalınlıkları 15 $\mathrm{cm}$ olarak tasarlanmıştır. Bütün yapılarda kolonlar ve kirişler çubuk elemanlarla, perde duvarlar ve döşemeler alan elemanları ile modellenmiş ve alan elemanlar 1x1 m boyutundaki elemanlara bölünmüştür. Modellerde karşılaştırmayı kolaylaştırmak için zemin etkisi ihmal edilmiş ve kolonlar ve perde duvarlar temel noktasında ankastre mesnetli olarak modellenmiştir. Eleman bağlantılarının monolitik olduğu ve 6 serbestlik derecesine sahip olduğu varsayılmıştır.

Beton sınıfı olarak TBDY2018'de belirtilen minimum dayanım (C25), donatılar için ise S420 kalitesi seçilmiştir. Çalışmada bütün elemanların aynı dayanıma sahip oldukları varsayılmıştır. Ayrıca döşeme üzerindeki hareketli yük $\mathrm{Q}=2 \mathrm{kN} / \mathrm{m}^{2}$, kirişler üzerindeki duvar yükü $8 \mathrm{kN} / \mathrm{m}$ olarak alınmıştır.

$144 \mathrm{~m}^{2}$ taban alanına sahip küçük modelde perde duvar önce plan ortasında tek parça olarak kullanılmış, daha sonra bu perde duvar iki eşit parçaya bölünerek ikinci modelde planın orta aksında, üçüncü modelde ise dış akslarda kullanılmıştır. Son modelde ise perde duvar dört eşit parçaya bölünerek köşelere yerleştirilmiştir (Şekil 2). $480 \mathrm{~m}^{2}$ 'lik büyük modelde ise, perde duvar yine ilk modelde plan ortasına yerleştirilmiş, daha sonra iki eşit parçaya bölünerek hem yatay hem de düşey akslar boyunca simetrik kullanılmıştır. Son olarak perde duvar dört eşit parçaya bölünerek yine hem yatay hem de düşey akslar boyunca simetrik yerleştirilmiştir (Şekil 3).

Deprem yüklemesi için mod birleştirme yöntemi kullanılmış ve kütlenin \%95'e ulaşabildiği mod sayısı dikkate alınmıştır.

Yapılan lineer elastik analizlerde perde duvar alanı sabit tutulan yapılarda perde duvar boyutunun küçültülerek sayısının arttırılmasının yapı davranışına hangi ölçüde etki ettiği anlaşılmaya çalışılmıştır. Perde duvarın 4 parça olarak kullanıldığı modellerde perde duvar kalınlığı arttıkça perde duvarın uzunluk/kalınlık $\left(l_{w} / t_{w}\right)$ oranı 6'dan daha küçük olmuştur. Fakat her durumda bu elemanların uzunluğu diğer kolonlardan fazla olduğundan, sistem rijitliğine daha fazla rijitlik katkısı vermektedir. Kolon ve perde duvar yapısal analizden ziyade genellikle tasarım kuralları bakımından birbirinden ayrıldığından bu çalışmada perde duvar ifadesi $\frac{l_{w}}{t_{w}}<6$ olan elemanlar için teorik olarak kullanılmıştır. Yukarıda bahsi geçen modeller daha sonra perde kalınlığı artırılarak yeniden analiz edilmiştir. Buradaki amaç ise perde duvar alanının (veya oranının) değişiminin yapının yük taşıma yeteneğine olan etkisinin belirlenmesidir.

Tablo 1. Formüllerin oluşturulması için tasarlanan modeller

\begin{tabular}{ccccc}
\hline \multirow{2}{*}{ Model } & \multirow{2}{*}{ Kat Alanı } & $\begin{array}{c}\mathbf{t}_{\mathbf{w}} \\
\mathbf{c m}\end{array}$ & $\begin{array}{c}\text { Perde Duvar Oranı } \\
\left(\mathbf{A}_{\mathbf{w i}} / \mathbf{A}_{\mathbf{p i}}\right)\end{array}$ & Kat Sayıları \\
\hline \multirow{3}{*}{$\mathrm{M} 1$} & \multirow{3}{*}{$144 \mathrm{~m}^{2}$} & 30 & 0.83 & $2-3-4-5-6-7-8$ \\
& & 40 & 1.25 & $2-3-4-5-6-7-8$ \\
& & 20 & 1.67 & $2-3-4-5-6-7-8$ \\
\hline \multirow{3}{*}{$\mathrm{M} 2$} & \multirow{2}{*}{$480 \mathrm{~m}^{2}$} & 30 & 0.25 & $2-3-4-5-6-7-8$ \\
& & 40 & 0.98 & $2-3-4-5-6-7-8$ \\
& & & 0.50 & $2-3-4-5-6-7-8$ \\
\hline
\end{tabular}




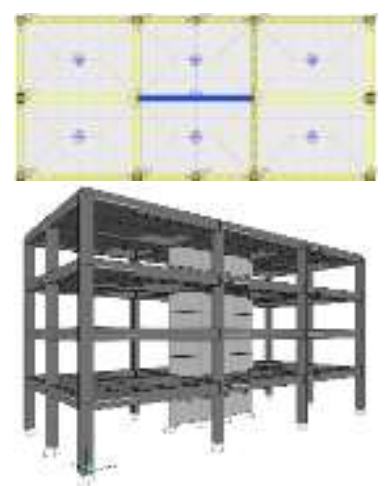

M1-1

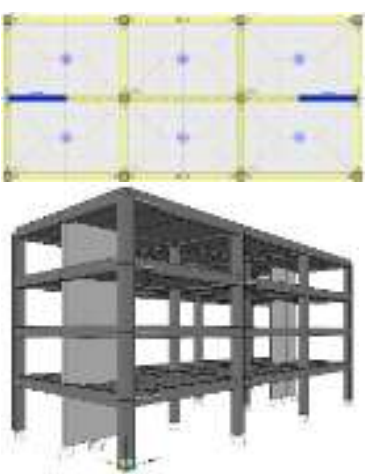

M1-2

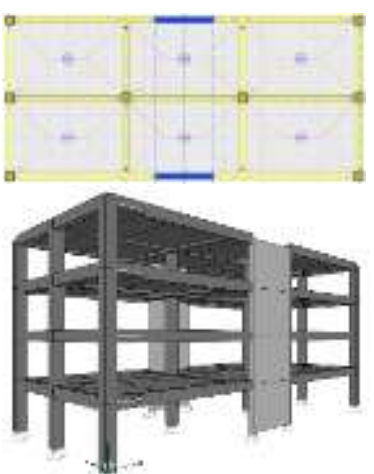

M1-3

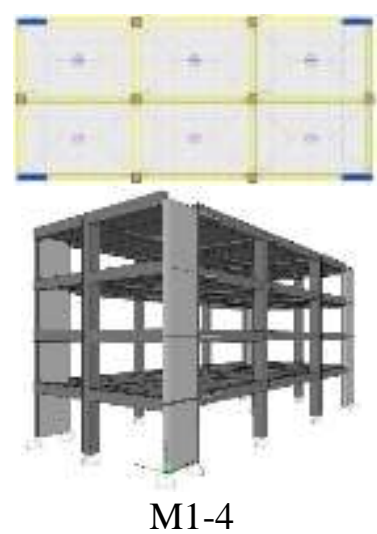

Şekil 2. $144 \mathrm{~m}^{2}{ }^{2}$ lik modeller

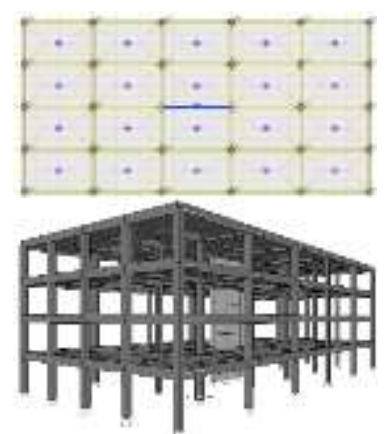

M2-1

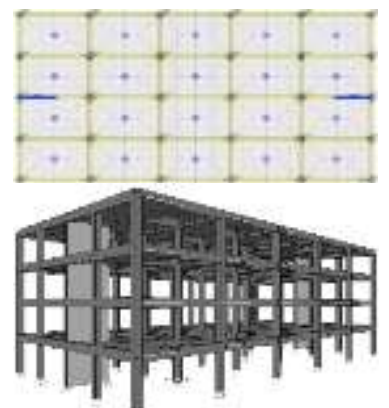

M2-5

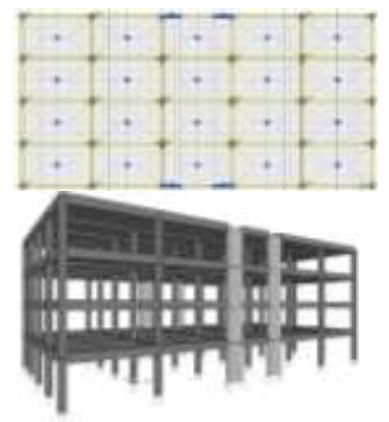

M2-9

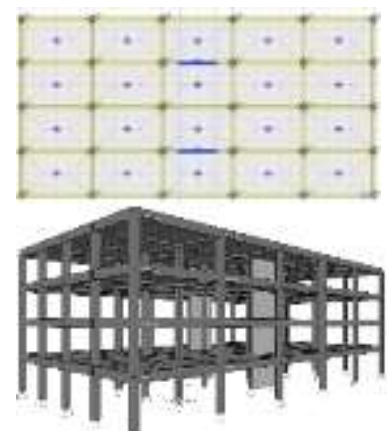

M2-2

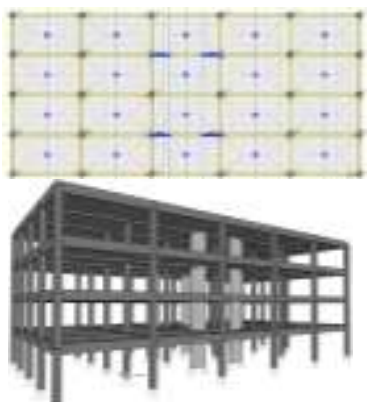

M2-6

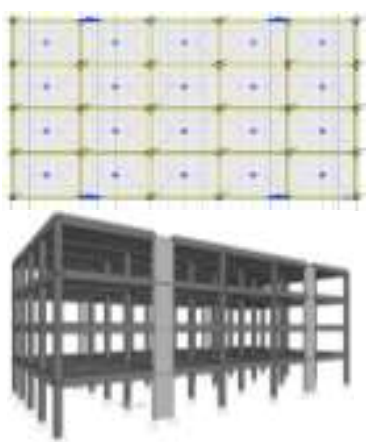

M2-10

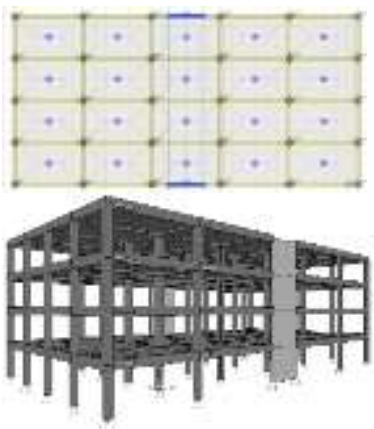

M2-3

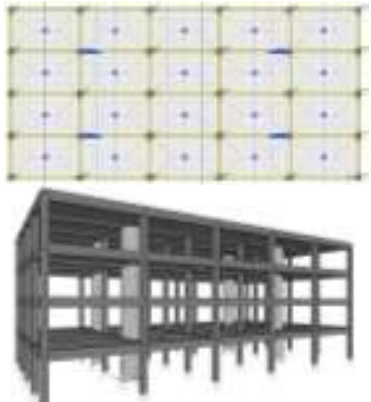

M2-7

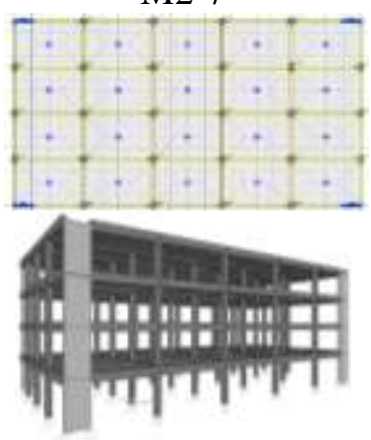

M2-11

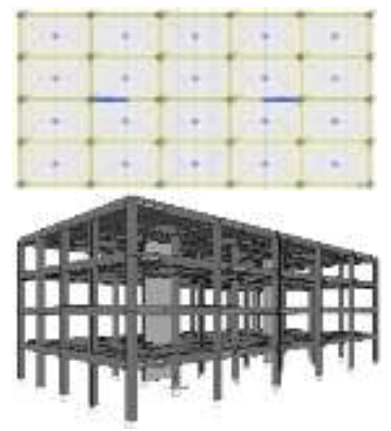

M2-4

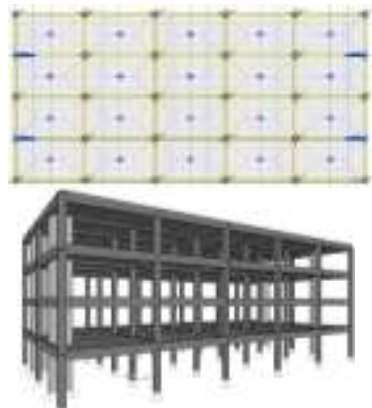

M2-8

Sekil 3. $480 \mathrm{~m}^{2}{ }^{\prime}$ lik modeller

\section{Bulgular ve Tartışma}

\subsection{Perde duvar devrilme momentinin değişimi}

Şekil 4, perde duvar tabanında oluşan toplam momentin $\left(\mathrm{M}_{\mathrm{sw}}\right)$ bina tabanında oluşan momente $\left(\mathrm{M}_{\mathrm{dev}}\right)$ oranı ile kat yüksekliği (N) arasındaki ilişkiyi vermektedir. Şekilden görüleceği üzere aynı perde duvar alanına sahip bir yapıda perde duvarların 2 ve 4 parçaya bölünmesi durumunda perde duvarın tabanında 
daha az momentler oluşmaktadır. Örneğin \%0.25 oranında perde duvar kullanılması durumunda, dört katlı bir binada perde duvar, devrilme momentinin \%57'sini taşırken, perde duvar iki eşit parça halinde kullanıldığında bu oran ortalama \%36'ya, dört eşit parça haline kullanıldığında ise ortalama \%20'ye düşmektedir. Perde duvarın moment etkinliğinin azalması perde uzunluğu ve dolayısıyla perde rijitliğinin azalmasının bir sebebidir. Perde duvar kalınlığının artması ile perde duvar oranı ve rijitliği artmakta, bu durumda perde duvarın taşıdığı momentlerde artışlar meydana gelmektedir. Perde duvar oranı \%1.67'ye çıkarıldı̆̆ında yine dört katlı binada tek perde duvar, devrilme momentinin \%79'unu, iki eşit perde duvar ortalama \%62'sini, dört eşit perde duvar ise ortalama \%38'ini taşımaktadır (Şekil 5). Perde duvar oranının artması ile perde duvarlar tarafından taşınan momentlerde her durumda artışlar gözlenmiştir.

Şekil 4’ten görüleceği üzere perde duvar iki eşit parçaya bölünerek dış akslara yerleştirildiğinde (M2-3) diğer iki parçalı perde duvar modellerinden daha etkili olmaktadır. M2-3 modelinde dört katlı binada devrilme momentinin \%38'i taşınırken, M2-2 modelinde \%36, M2-4 modelinde \%33, M2-5 modelinde \%36 oranında taşınmaktadır. Perde duvar dörde bölündügünde yine devrilme yönü dikkate alındığında en dış akslarda (M2-8 ve M2-11) kısmen daha etkili olacaktır. Bu etkinlik perde duvar oranından çok az etkilenmektedir. M2-8 ve M2-11 modellerinde taşınan moment devrilme momentinin $\% 21$ 'i olurken, M2-6 modelinde \%19, diğer modellerde ortalama \%20 olmaktadır. Sonuç olarak perde duvar parçalara bölündüğünde devrilme yönü dikkate alındığında merkeze yakın yerleştirilmesi ile perde duvarların etkinliği azalmakta, dış akslara yerleştirilmesi durumunda daha etkin olacağ belirlenmiştir. Burulma rijitliği üzerine yapılmış çalışmalarda da perde duvarların dış akslara yerleştirilmelerin daha faydalı olabileceği belirtilmiştir $[14,15]$.
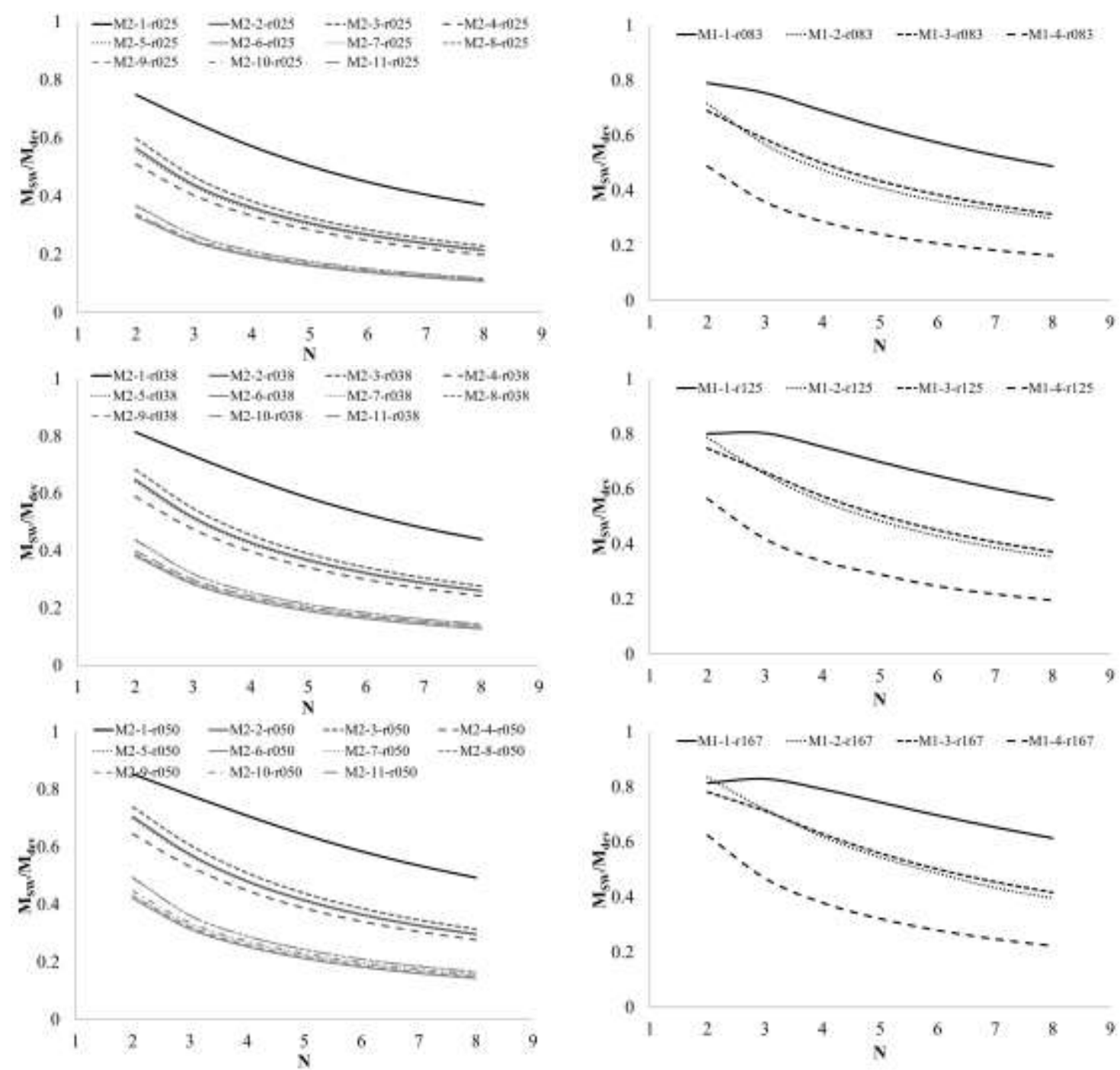

Şekil 4. Perde duvarların taşıdıkları momentin perde duvar sayısı ve kat sayısına göre değişimi. 
Grafiklerden kat yüksekliğine bağlı olarak perde duvarların taşıdığı momentlerin azaldığı da görülebilir. Sonuç olarak, aynı perde duvar alanına sahip sistemlerde perde duvar uzunluğu kısaltılarak perde duvar sayısının arttırılmasının perde duvarlar tarafından taşınan devrilme momentlerinde azalmaya sebep olduğu, kat sayısı arttıkça perde duvar etkinliğinin daha da azaldığı söylenebilir. Şekil 5 'ten ayrıca kat yüksekliği azaldıkça perde duvarlar tarafından taşınan momentlerin perde duvar oranı ile çok fazla değiştiği, kat yüksekliğin artması ile perde duvar oranının etkinliğinin azaldığı ve taşınan momentlerin birbirine yaklaştı̆̆ı görülebilir.

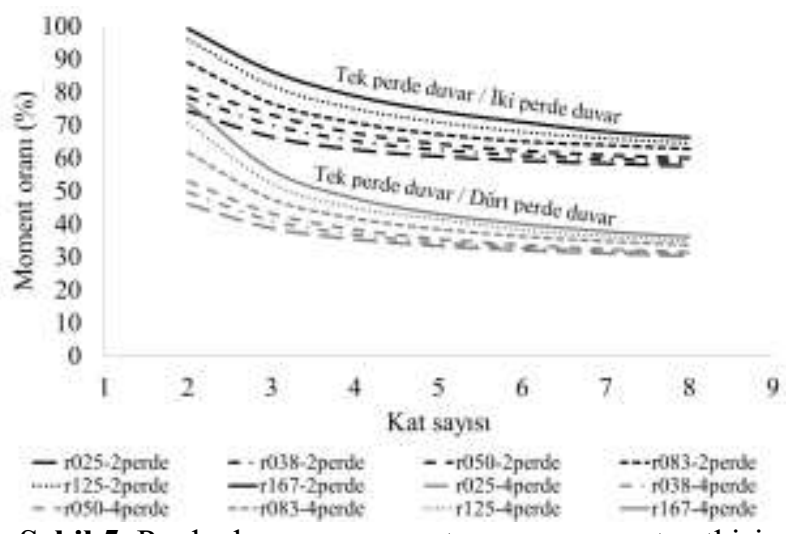

Şekil 5. Perde duvar sayısının taşınan momente etkisi

\subsection{Perde duvar taban kesme kuvvetinin değişimi}

Perde duvarlar tarafindan taşınan momentte olduğu gibi taban kesme kuvvetinde de perdeleri parçalara bölmek perde etkinliğinde düşüşe sebep olmaktadır (Şekil 6). Bu durum yine perde duvar rijitliğinin azalması ile açıklanabilir. Örneğin $\% 0.25$ perde duvar oranına sahip dört katlı modelde tek perde duvarın kullanılması durumunda perde duvar, toplam taban kesme kuvvetinin $\left(\mathrm{V}_{\mathrm{t}}\right) \% 81$ 'ini taşırken, perde duvar oranını sabit tutup perde duvar sayısını ikiye çıkarmak, perde duvarlar tarafindan taşınan taban kesme kuvvetini $\left(\mathrm{V}_{\mathrm{sw}}\right)$ yaklaşık \%75'lere düşürmektedir. Perde duvar aynı şekilde dört eşit parçaya bölündüğünde ise perde duvarlar tarafindan taşınan taban kesme kuvveti yaklaşık \%66 seviyelerine düşmektedir. Perde duvar oranı \%1.67'ye çıkarıldığında dört katlı bina için tek perde duvar, toplam taban kesme kuvvetinin \%96'sını taşırken, perde duvar iki eşit parçaya bölündüğünde bu oran \%92'ye, dört eşit parçaya bölündüğünde ise \%83'e düşmektedir. Perde duvarın büyüklüğü taşınan kesme kuvvetini doğrudan etkilemektedir.

Perde duvarların taşıdığı kesme kuvvetlerinin perde duvar konumu ile olan ilişkisi incelendiğinde, bina merkezine yerleştirilen perde duvarların daha fazla kesme kuvveti aldıkları görülebilir (Şekil 6). Dört perde duvarlı modellerden daha iyi görüleceği üzere perde duvarlar bina merkezine yakın yerleştirilmeleri durumunda daha fazla taban kesme kuvvetine maruz kalmaktadır. Bina köşelerine perde duvarlar yerleştirildiğinde perde duvar etkinliği önemli oranda düşmektedir. $\mathrm{Bu}$ durum perde duvarların taşıdığı momentlerden farklıdır. Bunun sebebi olarak, devrilme momentlerine maruz kalan sistemlerde en büyük eğilme gerilmelerinin merkezden en uzak noktalarda oluşması gösterilebilir. Aynı şekilde kesme kuvvetlerine maruz kalan sistemlerde en büyük kesme gerilmeleri merkezde oluşmaktadır. Dolayısıyla elde edilen sonuçların olağan sonuçlar olduğu belirlenmiştir.

Şekil 7, perde duvar oranı sabit tutularak perde duvarın ikiye ve dörde bölünmesi durumunda perde duvarlar tarafından taşınan toplam kesme kuvvetinin tek perde duvarın taşıdığı kesme kuvvetine oranını göstermektedir. Şekilden görüleceği üzere perde duvar oranı sabit tutulup perde duvar sayısı artırıldığında perde duvarlar tarafindan taşınan kesme kuvveti perde duvarın her konumu için azalmaktadır. Perde duvar kalınlığı, bir başka deyişle perde duvar oranı, artırıldığında taşınan kesme kuvvetinin arttığı, fakat taşınan kesme kuvvetinin perde duvar sayısı dikkate alındığında aynı oranlarda değiştiği görülebilir.

Bunlara ilave olarak grafiklerden görüleceği gibi, kat sayısındaki artış ile beraber $V_{s w} / V_{t}$ değerinde \%3-\%6 oranında bir düşüş gözlenmektedir. Sonuç olarak perde duvar alanı sabit tutulup boyu kısaltılarak sayısı arttırıldığında perde duvar taban kesme kuvvetinin azaldığı, bu azalma miktarının kat sayısından çok az etkilendiği söylenebilir. 

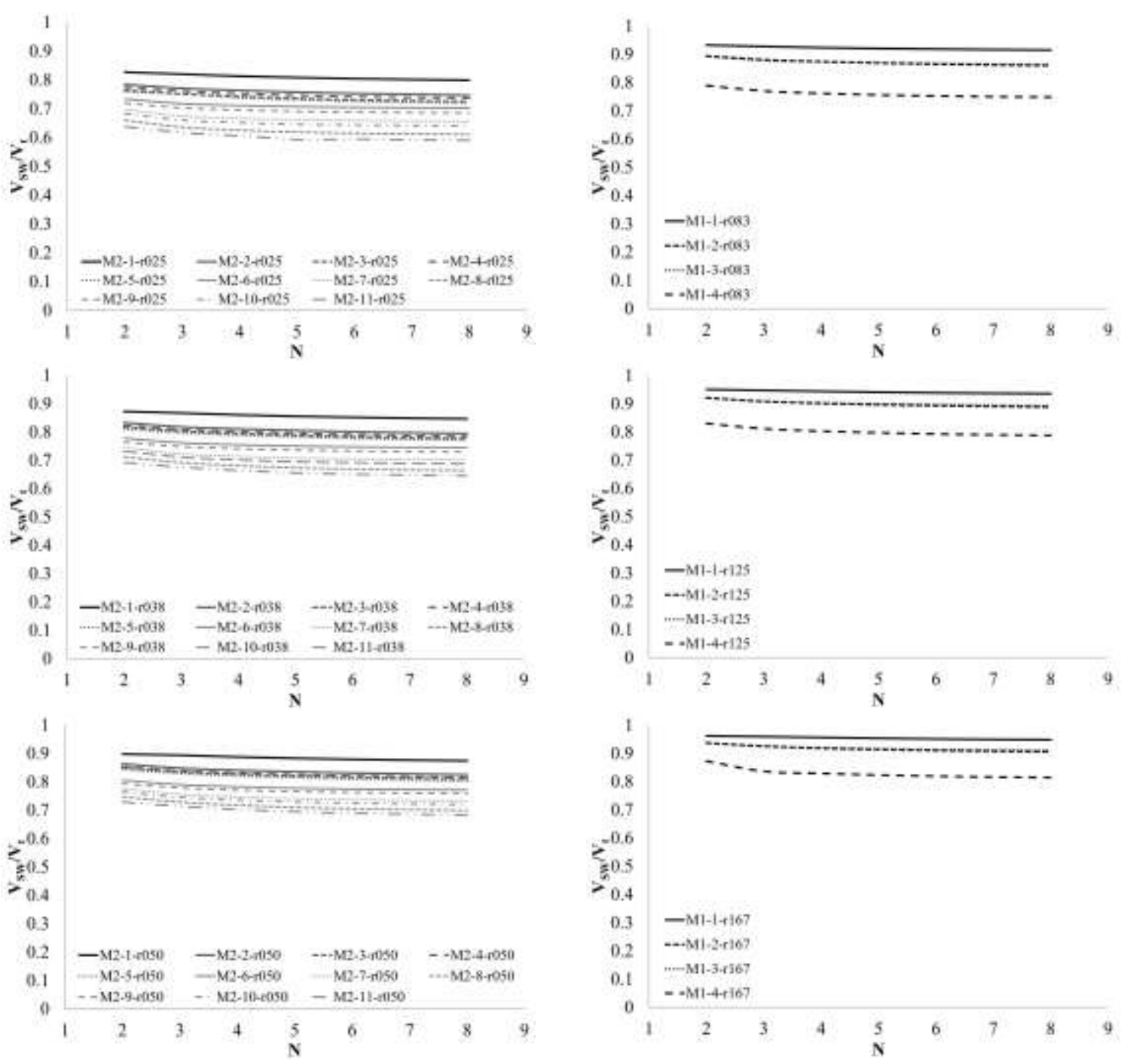

Şekil 6. Perde duvarların taşıdığı kesme kuvvetinin perde sayısına göre değişimi

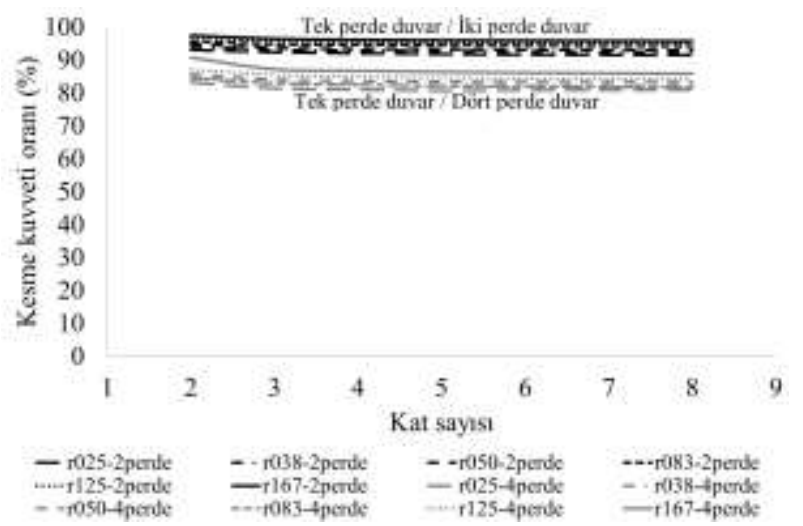

Şekil 7. Perde duvar sayısının taşınan kesme kuvvetine etkisi

\subsection{Perde duvar ile periyot ilişkisi}

Perde duvarların uzun kenarlarının kısa kenarlarına oranı büyük olduğundan bu elemanlar kolonlara göre oldukça rijittir. Perde duvarların bu özellikleri onları deprem yükleri için vazgeçilmez kılmaktadır. Görüleceği üzere aynı alana sahip perde duvarları tek parça kullanmak yapıya önemli bir rijitlik katkısı sağlayacağından yapının periyodunda düşüşü beraberinde getirmektedir (Şekil 8). Perde duvar alanı sabit tutulup sayısı arttırıldığında rijitlik kaybı yaşanacağından periyotlarda artış görülmektedir (Şekil 9). Şekillerden görüleceği üzere iki ve dört perde duvarlı modellerin periyotları tek perde duvarlı model 
periyodundan ayrılarak üstte kümelenmiştir. Şekillerden ayrıca kat sayısının artması ile periyodun yaklaşık lineer olarak arttığı da görülebilir. Yapıda doğrusal olmayan davranış dikkate alınmadığından periyodun yükseklik ile değişmesi olağan olmaktadır.

Şekillerde farklı perde duvar oranlarında periyodun nasıl değiştiği de gözlenebilmektedir. Perde duvar oranı arttıkça, yapı rijitliğinin arttığı ve bunun sonucu olarak da periyodun azaldığı görülebilir. Perde duvarların bölünmesi durumunda merkeze yakın yerleştirilmeleri ile (iki perde duvarlı modellerde M2-4, dört perde duvarlı modellerde M2-6 ve M2-9) rijitliğin daha fazla artacağı ve periyodun diğer modellerden daha düşük elde edilebileceği belirlenmiştir.
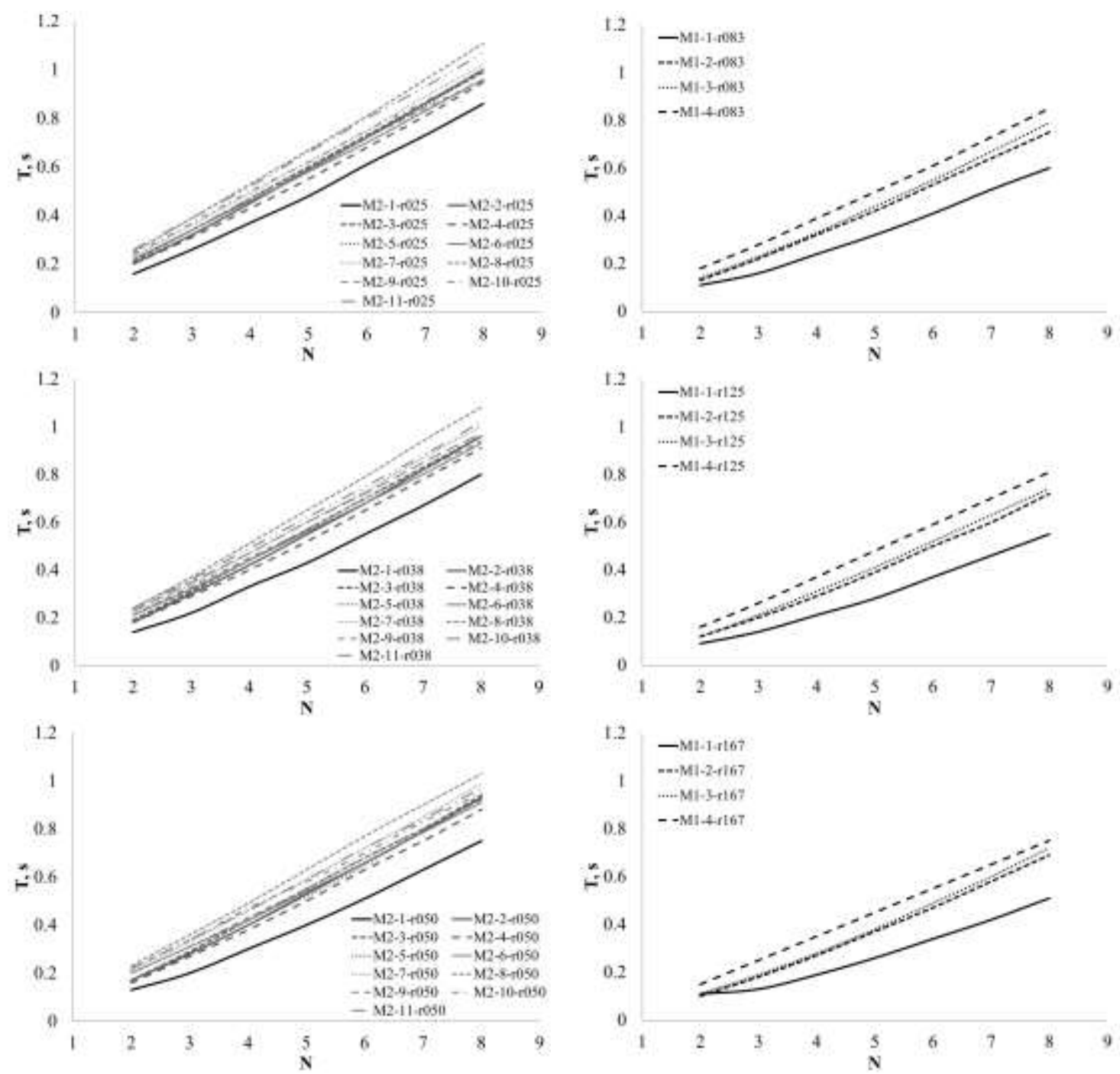

Şekil 8. Periyodun kat sayısı ve perde duvar sayısına göre değişimi.

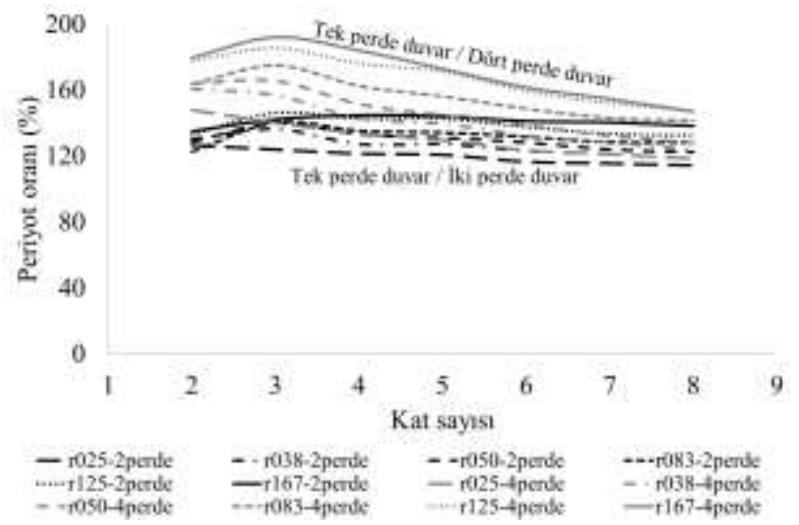

Şekil 9. Perde duvar sayısının periyoda etkisi 


\subsection{Perde duvar ile tepe deplasman iliş kisi}

Deprem esnasında taşıyıcı sistemlerin deplasman ve göreli kat ötelemeleri oldukça önemlidir. 2007 Deprem Yönetmeliği'ne göre göreli kat öteleme değerinin \% 2 değerini geçmemesi gereklidir. 2018 Deprem Yönetmeliği'nde ise betonarme binalar için izin verilen göreli kat öteleme oranı $\% 0.8 / \lambda$ şeklinde ifade edilmektedir. Burada $\lambda$ katsayısı, binanın göz önüne alınan deprem doğrultusundaki hâkim titreşim periyodu için DD-3 deprem yer hareketi için hesaplanan elastik tasarım spektral ivmesinin, DD-2 deprem yer hareketinin için hesaplanan elastik tasarım spektral ivmesine oranı olarak verilmektedir.

Şekil 10'da verilen grafiklerde tepe deplasmanın $\left(\mathrm{D}_{\text {top }}\right)$ bina yüksekliğine $\left(\mathrm{H}_{\mathrm{t}}\right)$ oranının kat sayısı, perde duvar sayısı ve perde duvar oranı ile ilişkisi verilmektedir. Şekillerden görüleceği üzere tek perde duvarlı modelin iki perde duvarlı modele, onun da dört perde duvarlı modele göre $\mathrm{D}_{\text {top }} / \mathrm{H}_{\mathrm{t}}$ değerleri daha düşük seviyededir. Yapı yüksekliği arttıkça perde duvar etkinliği düşmekte ve modellerin tepe deplasmanları büyümekte fakat tepe deplasman oranları düşmektedir. Örneğin $\% 0.25$ perde duvar oranına sahip modellerde tek perde duvarl 2 katl modelde tepe deplasman $0.78 \mathrm{~cm}$ iken, 4 perde duvarlı modelde $1.97 \mathrm{~cm}$ olmakta (oran 2.53), tek perde duvarlı 8 katlı modelde tepe deplasman değeri yaklaşık $19.1 \mathrm{~cm}$ iken bu değer dört perde duvarlı sistemde 25.4 cm'ye kadar çıkmaktadır (oran 1.33). Buradan, perde duvar alanı sabit tutulup perde duvar sayısı arttırıldığında, bir başka deyişle daha kısa fakat daha fazla sayıda perde duvar oluşturulduğunda, perde duvar rijitliği azaldığından tepe deplasmanlarda artış olduğu sonucuna varılabilmektedir.

Perde duvar oranının (perde duvar alanının bina taban alanına oranı) artması ile tepe deplasmanların azalması beklenmektedir. Perde duvar oranı 0.25 ile 0.50 olan modeller kıyaslandığında perde duvar oranının 2 katına çıkarılması ile maksimum tepe deplasmanda yaklaşık \%15 oranında bir düşüş görülmüştür (Şekil 10). Deplasman farkının 2 ve 3 katlı yapılarda perde duvar oranı farkından çok etkilenmediği, kat sayısının artışı ile bu farkın önemli hale geldiği söylenebilir.

Perde duvarların sisteme kattıkları rijitlikler bina periyodunu ve nihayetinde binaya etkiyen yatay deprem yüklerini etkilemektedir. Perde duvarların düşük rijitlik katkısı verdiği modellerde $(\% 0.25$ perde duvar oranı, iki veya dört perde duvarlı modeller) belirli kat seviyelerinden sonra periyotlardaki büyük artışlar neticesinde yapıya daha az deprem yükü etkimekte ve bu durum $\mathrm{D}_{\text {top }} / \mathrm{H}_{\mathrm{t}}$ değerlerinde ani düşüşlere yol açmaktadır. Perde duvarların büyük rijitlik katkısı verdiği modellerde nispeten daha orantılı $\mathrm{D}_{\mathrm{top}} / \mathrm{H}_{\mathrm{t}}$ değerleri elde edilmiştir.

Perde duvarların konumlarının tepe deplasman oranlarına etkisi incelendiğinde bir önceki bölümde gözlenen rijitlik katkısının burada da etkili olduğu ve perde duvarların merkeze yerleştirilmeleri ile daha etkin rjitlik katkısı vererek en düşük tepe deplasman değerleri elde edilebileceği belirlenmiştir. 

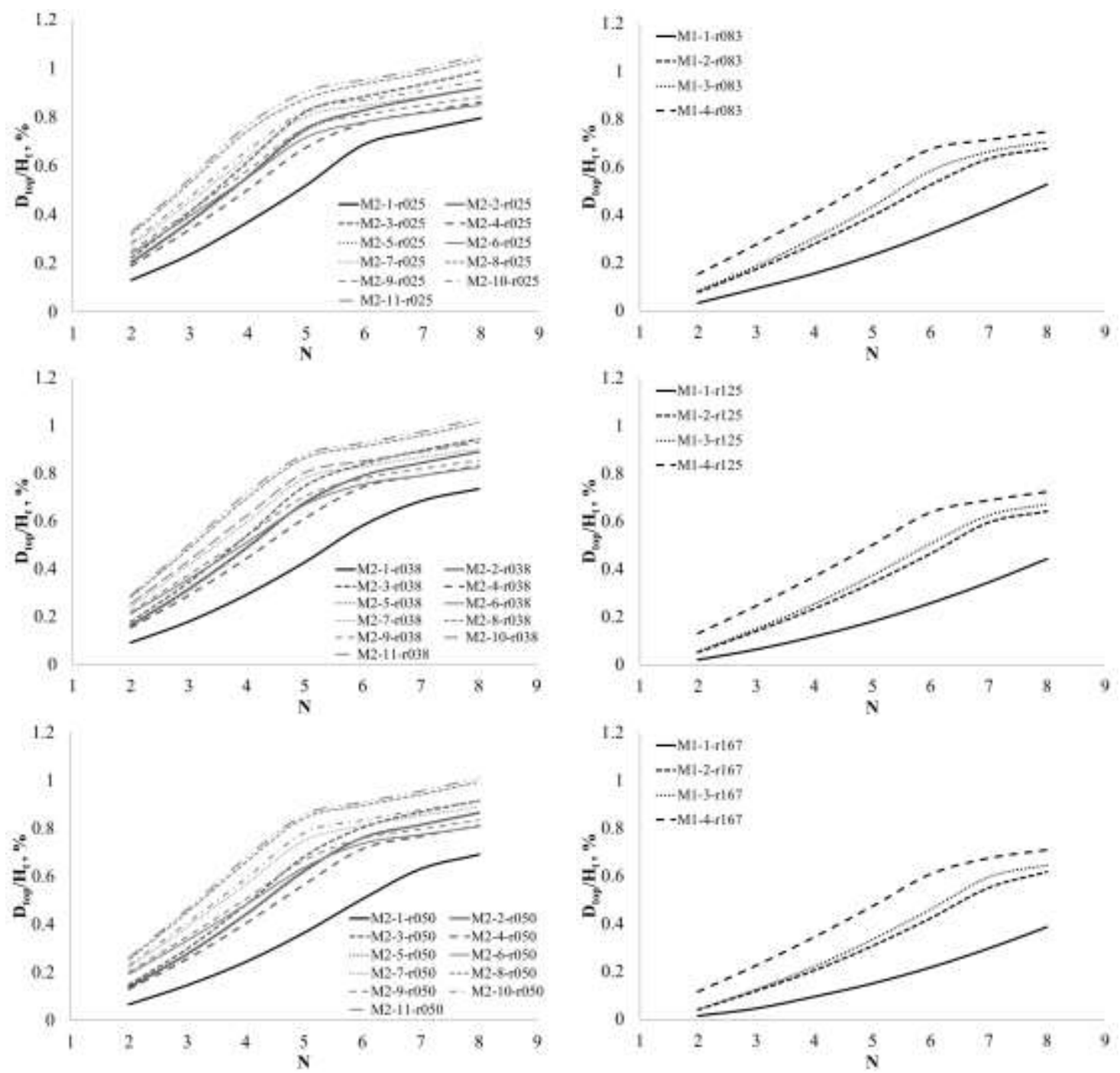

Şekil 10. $D_{\text {top }} / H_{t}$ oranının perde duvar sayısı, yerleşimi ve kat sayısı ile değişimi.

\section{5. $\mathrm{M}_{\mathrm{dev}} / \mathrm{V}_{\mathrm{t}}$ ve yapı yüksekliği iliş kisi}

Binadaki toplam taban devrilme momenti $\left(\mathrm{M}_{\mathrm{dev}}\right)$ ile toplam taban kesme kuvveti $\left(\mathrm{V}_{\mathrm{t}}\right)$ 'in oranının aynı perde duvar alanına fakat farklı perde duvar sayısına sahip sistemlerde hangi oranda değiştiği Şekil 11 'de incelenmiştir. Şekillerden görüleceği üzere tek, 2 ve 4 perdeli sistemlerin tümü için aynı lineer ilişki ortaya çıkmıştır. Bilindiği üzere deprem yükünü hesaplamada basit bir yöntem olarak gösterilen eşdeğer deprem yükü metodunda bile yapıya etkiyen momenti bulmak birkaç adım sürebilmektedir. Ancak Şekil 11 dikkatlice incelendiğinde grafiğin eğiminin yapının efektif yüksekliğini, bu efektif yükseklik ile taban kesme kuvvetinin çarpımının da devrilme momentini verdiği görülecektir. 315 farklı modelin sonuçlarından efektif yüksekliğin (taban kesme kuvvetinin bina yüksekliği boyunca etkidiği hayali nokta) Eş. 4 ile (grafiklerde mavi çizgiler) temsil edilebileceği görülmüştür. TBDY2018'de verilen eşdeğer deprem yükü yönteminde katlara etkiyen deprem yüklerinin yaklaşık üçgensel dağıldığ (baskın titreşim modunda bütün katların aynı doğrultuda deplasman yapacakları varsayımı sebebi ile), üst katlarda fazla alt katlarda daha az deprem yükünün oluştuğu, bu durumda taban kesme kuvvetinin hayali noktasının zeminden itibaren $2 / 3 \mathrm{H}$ yüksekliğinde olduğu dolaylı olarak belirtilmektedir [20] (Şekil 11, turuncu çizgiler). Eş. 4 ile TBDY2018 arasında küçük farklar olduğu, Eş.4'ün güvenlik seviyesinin nispeten daha fazla olduğu görülebilir.

$$
\mathrm{H}_{\mathrm{eff}}=\mathrm{H}^{0.89}
$$



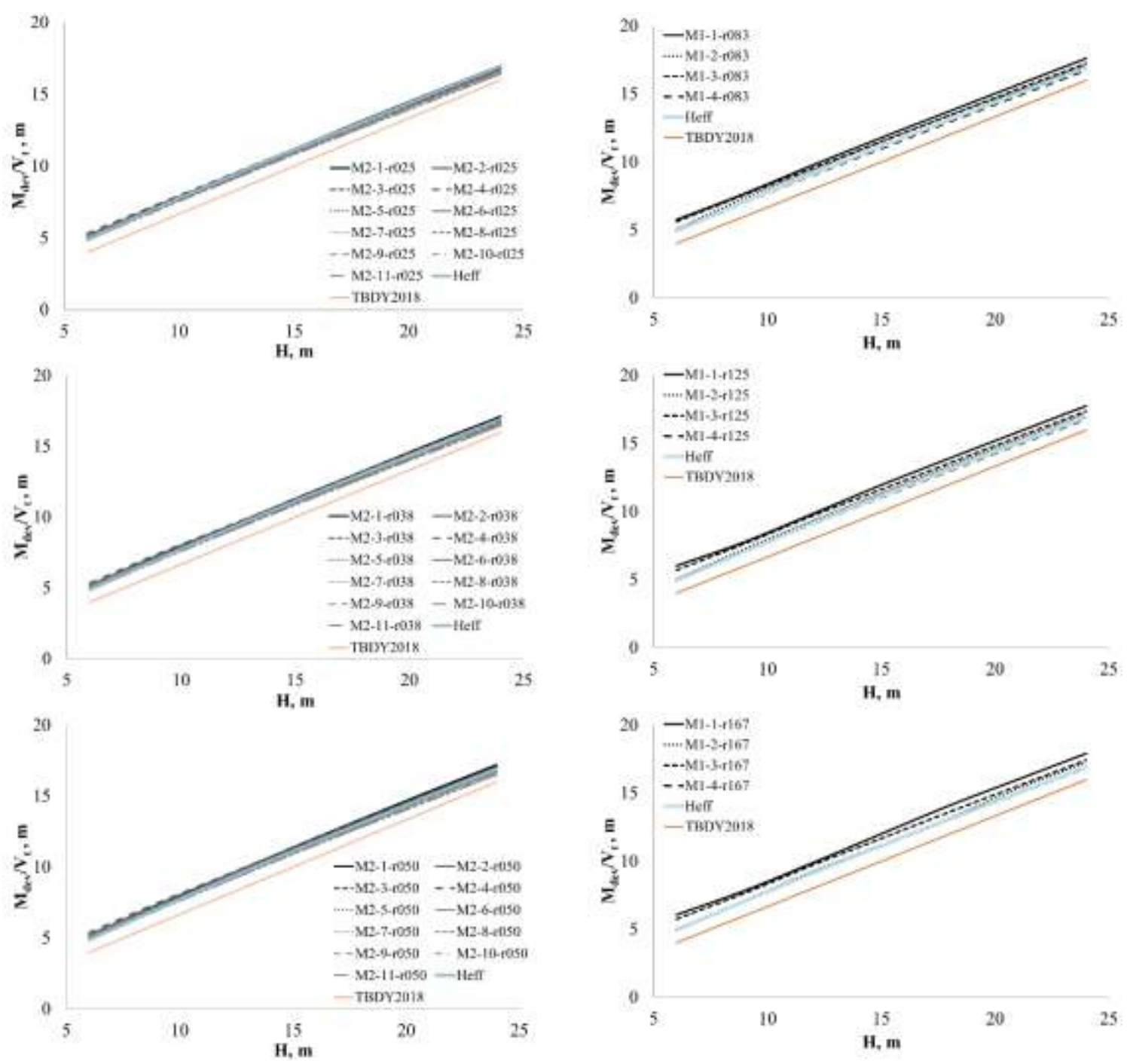

Şekil 11. $\mathrm{M}_{\mathrm{dev}} / \mathrm{V}_{\mathrm{t}}{ }^{\prime}$ in yüksseklik ile ilişkisi ve efektif yükseklik.

\section{6. $\mathrm{M}_{\mathrm{Sw}} / \mathrm{V}_{\mathrm{Sw}}$ ve yapı yüksekliği ilişkisi}

Bir önceki bölümde yapının tabanında meydana gelen toplam devrilme momentinin toplam taban kesme kuvvetine oranının bütün perde duvar oranları için aynı olduğu ve kat yüksekliği ile lineer değiştiği söylenmişti. Perde duvarların tabanındaki toplam devrilme momentlerinin perde duvarların tabanındaki taban kesme kuvvetine oranının kat yüksekliği ile değişimi Şekil 12'deki grafiklerde verilmektedir. Grafiklerden görüleceği üzere perde duvarı tek parça halinde merkezde kullanmak en büyük $\mathrm{M}_{\mathrm{SW}} / \mathrm{V}_{\mathrm{SW}}$ değerlerini verirken perde duvar oranını sabit tutup sayısı ikiye çıkarıldığında değerler yaklaşık 1.5 kat düşmekte, perde duvar sayısı dörde çıkarıldığında ise düşüş 2.5 kat civarında olmaktadır. Bu durum perde duvar oranı sabit tutulup sayısı artırıldığında perde duvarların etkinliğinin azaldığına işaret etmektedir. $\mathrm{M}_{\mathrm{SW}} / \mathrm{V}_{\mathrm{SW}}$ için hesaplanan düşüşler kat yüksekliği azaldıkça azalmaktadır. Kat yüksekliği azaldıkça devrilme momentleri ve tepe deplasmanlar azalacağı için perde duvarlar daha az zorlanacaktır.

Aynı perde duvar oranı için perde duvar sayısının artırılması ile $\mathrm{M}_{\mathrm{Sw}} / \mathrm{V}_{\mathrm{Sw}}$ değerlerinin kat yüksekliği ile pek fazla değişmediği yine grafiklerden görülebilir. İki perde duvarlı sistemlerde $\mathrm{M}_{\mathrm{SW}} / \mathrm{V}_{\mathrm{Sw}}$ değerlerinin kat yüksekliği ile çok az değiştiği, dört perde duvarlı sistemlerde ise düşük perde duvar oranlarında hemen hemen hiç değişmediği, perde duvar oranı arttıkça değişimin görüldügü fakat çok düşük seviyelerde kaldığı gözlenmiştir. 

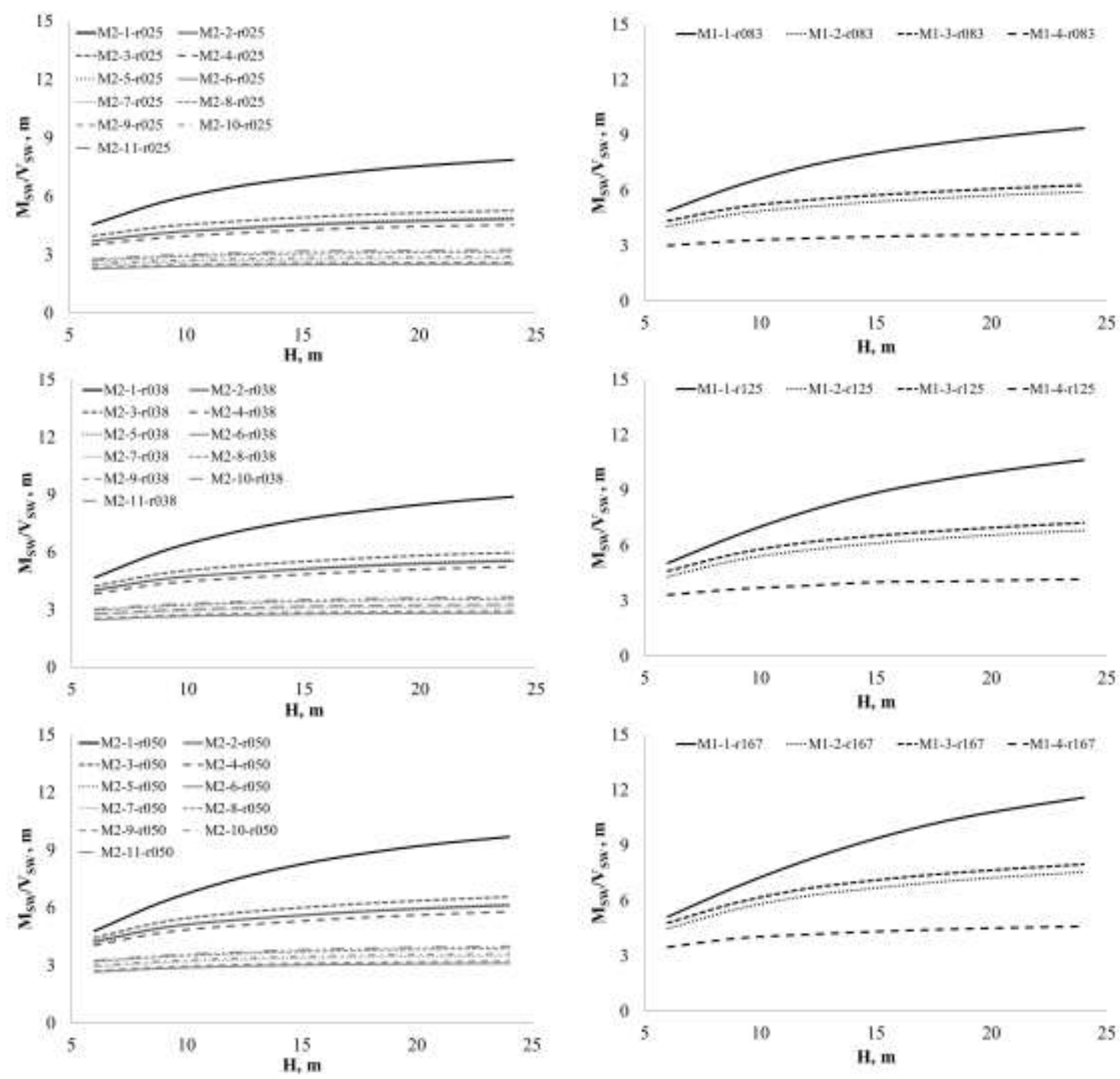

Şekil 12. $\mathrm{M}_{\mathrm{SW}} / \mathrm{V}_{\mathrm{Sw}}$ 'in yükseklik ile ilişkisi.

\section{Sonuçlar}

Günümüzde betonarme binaların güçlendirmesinde perde duvarlar yaygın olarak kullanılmakta, binalar için gerekli perde duvar oranları ya bina taban alanı ya da toplam alan ile ilişkili bir şekilde verilmektedir. Ancak güçlendirme esnasında kullanılacak perde duvar miktarı ve yerleşim yeri ile ilgili pratik bir formül öne sürülmemiş olup, güçlendirme esnasında perde duvarlar bilgisayar programları kullanılarak deneme yanılma yoluyla hesaplanıp yerleştirilmektedir. Bu da güçlendirme projesi yapan mühendisler için zaman kaybına sebep olmaktadır.

Yapılan bu çalışmada iki farklı kat alanına, üç farklı perde duvar oranına ve yedi farklı kat sayısına sahip 315 model üzerinde yapılan analizler neticesinde kesme kuvveti, moment, yapı periyodu ve tepe deplasmanlar elde edilmiştir.

Perde duvarların yapıda güçlendirme elemanı olarak kullanılma amacı sahip oldukları yüksek rijitliktir. Aynı perde duvar alanına sahip bir yapıda, perde duvarın iki veya dört parçaya bölünerek yerleştirilmesi durumunda perde duvarlar tarafindan taşınan momentte azalma olduğu, azalan bu momentlerin kapasitesi yetersiz mevcut kolonlar tarafından taşınacağı görülmüştür. Perde duvarların çok parçalı kullanılması sonucunda boylarındaki azalma sebebiyle rijitlikleri çok fazla düştüğünden moment etkinliklerinde düşüş gözlenmiştir. Yapılan analizlerde tek perde duavrlı sistemin iki eşit parçaya bölünmesi ile perde duvarlar tarafindan taşınan momentin \%20-\%25, dört eşit parçaya bölünmesi ile $\% 50$ oranında düşüş gösterdiği gözlemlenmiş̧tir.

Perde duvarlar tarafından taşınan kesme kuvveti de tıpkı momentte olduğu gibi perde duvar sayısından etkilenmektedir. Perde duvarları aynı alana sahip olacak şekilde parçalara bölerek 
yerleştirmek perde duvarın kesme kuvveti etkinliğinde düşüşe sebep olmuştur. Yapılan analizlerde perde duvarın kesme kuvveti etkinliğinin iki eşit parçaya bölünmesiyle \%6-\%8, dört eşit parçaya bölünmesiyle \%10-\%22 oranında düştügü gözlemlenmiştir.

Dört perde duvarlı modeller üzerinde yapılan analizler neticesinde perde duvarların bina merkezine yakın yerleştirilmesi durumunda kesme kuvveti etkinliğinin arttığı, binanın dış kısımlarına yerleştirilmesi durumunda ise daha fazla moment taşıyacakları gözlemlenmiştir.

Perde duvarlar sahip oldukları yüksek rijitlikleri sayesinde yapının ötelenmesini önemli ölçüde azaltmaktadır. Yapının ötelenmesinin düşmesi sonucu yapı periyodunda düşüş gözlemlenmiştir. Analizlerde tek perde duvarlı sistem periyodunun iki ve dört perde duvarlı sisteme göre daha az olduğu görülmüştür. Deprem esnasında taşıyıcı sistemlerin deplasman ve göreli kat ötelemeleri oldukça önemlidir. Tepe deplasmanlar kıyaslandığında; tek perde duvarlı modelin iki perde duvarlı modele, iki perde duvarlı modelin ise dört perde duvarlı modele göre daha az olduğu belirlenmiştir. Buradan perde duvar oranı sabit tutulup perde duvar sayısı artırıldığında rijitliğin düşmesi sebebi ile tepe deplasmanlarda artışlar gözlenmiştir. Ayrıca perde duvar oranının iki katına çıkarılması tepe deplasmanda yaklaşık \%15'lik bir düşüşü de beraberinde getirmiştir. Ancak iki ve üç katlı yapılarda deplasmanın perde duvar oranına bağlı olarak çok fazla değişmediği görülmüştür.

Analizlerde tek, iki ve dört perde duvarlı sistemlerin tümü için $\mathrm{M}_{\text {dev }} / \mathrm{V}_{\mathrm{t}}$ değerinin aynı lineer ilişkiye sahip olduğu belirlenmiştir. $\mathrm{M}_{\text {dev }} / \mathrm{V}_{\mathrm{t}}$ ilişkisi efektif yükseklik olarak nitelendirilmekte ve bu çalışma kapsamındaki analizler neticesinde $\mathrm{H}_{\mathrm{eff}}=\mathrm{H}^{0.89}$ olarak bulunmuştur. Basit bir yöntem olan eşdeğer deprem yükü metodunda yapıyı etkiyen momentin birkaç adımda elde edilebildiği bilinmektedir. Ancak önerilen $\mathrm{H}_{\text {eff }}$ ile taban kesme kuvvetinin çarpımı neticesinde yapının devrilme momenti kolayca elde edilebilecektir.

\section{Teșekkür}

Bu çalışma Van Yüzüncü Yıl Üniversitesi Bilimsel Araştırma Projeleri Koordinasyon Birimi tarafindan FYL-2018-7232 nolu proje kapsamında desteklenmiştir.

\section{Yazarların Katkısı}

Yazarlar makaleye eşit katkı vermiştir.

\section{Çıkar Çatışması Beyanı}

Yazarlar arasında herhangi bir çıkar çatışması bulunmamaktadır.

\section{Araştırma ve Yayın Etiği Beyanı}

Yapılan çalışmada araştırma ve yayın etiğine uyulmuştur.

\section{Kaynakça}

[1] AFAD, 2014. https://www.afad.gov.tr/upload/Node/17944/xfiles/mudahale_-iyilestirme-vesosyoekonomik-acidan-2011-van-depremi-raporu_2_.pdf Müdahale İyileştirme ve Sosyoekonomik Açıdan 2011 Van Depremi, AFAD, Ankara, Turkey. (Erişim tarihi: 10.12.2018).

[2] Erdil B. 2016. Why RC buildings failed in the 2011 Van, Turkey, Earthquakes: construction versus design practices. Journal of Performance of Constructed Facilities, 31 (3): 04016110.

[3] Sezen H., Whittaker A.S., Elwood K.J., Mosalam K.M. 2003. Performance of reinforced concrete buildings during the August 17, 1999 Kocaeli, Turkey earthquake, and seismic design and construction practise in Turkey. Engineering Structures, 25 (1): 103-114.

[4] Akansel V., Ameri G., Askan A., Caner A., Erdil B., Kale Ö., Okuyucu D. 2014. The 23 October $2011 \mathrm{Mw}=7.0$ Van (Eastern Turkey) Earthquake: Interpretations of Recorded Strong Ground Motions and Post-Earthquake Conditions of Nearby Structures. Earthquake Spectra, 30 (2): $657-$ 682. 
[5] Wallace J.W. 2012. Performance of structural walls in recent earthquakes and tests and implications for US building codes. In Proceedings of the 15th World Conference on Earthquake Engineering.

[6] Aktan S., Kıraç N. 2010. Betonarme binalarda perdelerin davranışa etkileri. Eskişehir Osmangazi Üniversitesi Mühendislik Mimarlık Fakültesi Dergisi, 23 (1):15-32.

[7] Kazaz I. 2016. Seismic deformation demands on rectangular structural walls in frame-wall systems. Earthq. Struct, 10 (2): 329-350.

[8] Wallace J.W. 1995. Seismic design of RC structural walls. Part I: new code format. Journal of Structural Engineering, 121 (1): 75-87.

[9] Yakut A., Soydaş O. 2010. Evaluation of shear wall indexes for RC buildings. In 9th US National and 10th Canadian Conference on Earthquake Engineering, p. Paper (No. 371).

[10] Burak B., Comlekoglu H. G. 2013. Effect of shear wall area to floor area ratio on the seismic behavior of reinforced concrete buildings. Journal of Structural Engineering, 139 (11): 19281937.

[11] Yurdakul O., Tunaboyu O., Avşar O. 2014. Effects of shear wall ratio on the seismic behavior of buildings having inadequate seismic resistance. 10th US National Conference on Earthquake Engineering (10NCEE) at: Anchorage, Alaska, USA

[12] Sozen M. 2001. As simple as it gets: The Anatolian formula for earthquake resistant design. Türkiye İnşaat Mühendisliği 16. Teknik Kongresi, Turkish Chamber of Civil Engineers, Ankara, Turkey.

[13] Ersoy U. 2013. A simple approach for preliminary design of reinforced concrete structures to be built in seismic regions. Teknik Dergi Digest, 24 (120): 1701-1715.

[14] Öztürk D., Nuhoğlu A., Bozdoğan K.B. 2005. Betonarme yapılarda beton sınıfının taşıyıcı sistem davranışına etkisi. Deprem Sempozyumu. 23-25 Mart 2005, Kocaeli, Türkiye. 506-511.

[15] Uçar T., Merter O. 2009. Planda perde yerleşiminin betonarme perde-çerçeveli binaların deprem davranışına etkisi. Dokuz Eylül Üniversitesi Mühendislik Fakültesi Mühendislik Bilimleri Dergisi, 11 (2): 11-18.

[16] Yoichi Higashi T.E., Ohkubo M., Shimizu Y. 1980. Experimental study on strengthening reinforced concrete structure by adding shear wall. In Proc. of the World Conf. on Earthquake Eng., Turkey, 7: 173-180.

[17] Yılmaz Ü., Arslan M., Kaltakcı M. 2010. Betonarme dış perde duvarla güçlendirilmiş çerçevelerin dayanım parametrelerinin deneysel ve analitik yöntemlerle irdelenmesi. TÜBAV Bilim Dergisi, 3 (1): 11-22.

[18] Ugalde D., Lopez-Garcia D. 2020. Analysis of the seismic capacity of Chilean residential RC shear wall buildings. Journal of Building Engineering, 31: 101369.

[19] Cando M.A., Hube M.A., Parra P.F., Arteta C.A. 2020. Effect of stiffness on the seismic performance of code-conforming reinforced concrete shear wall buildings. Engineering Structures, 219: 110724.

[20] TBDY2018. Deprem etkisi altında binaların tasarımı için esaslar. Afet ve Acil Durum Yönetimi Başkanlığı, Ankara, Türkiye.

[21] Erdil B. 2017. Dikdörtgen kesitli betonarme perde duvarların taşıma gücü momenti hesabı için basit bir yaklaşım. Pamukkale Üniversitesi Mühendislik Bilimleri Dergisi, 23 (3): 209-220.

[22] Computers and Structures Inc. (CSI) SAP2000 "Linear and Nonlinear Static and Dynamic Analysis and Design of Three-Dimensional Structures". Version 14, Berkeley, CA. 